has upon the fermentation processes in the soil. To some people the very simplicity of this answer may be an obstacle in the way of its acceptance. Here and there an open dust bin, a choked house drain, or a dirty pig-stye, is so much a matter of course, from the popular point of view, that no particular importance is attached to it; yet attention to, or neglect of, these apparently trivial matters makes all the difference between wholesome or unwholesome $t$ nvironm $\mathrm{nt}$ - this in turn determines the balance betwern health and disease, and often betwixt life and death.

Unsanitary agents such as we are dealing with work their effect by depressing vitality, making the strong less strong and the weak more weak, so that in any given case it is merely a question of what reserve of vitality there may be, whether the person is or is not able successfully to contend against the depression wrought by the unsanitary agent; if not, then invasion by disease or destruction by death ensues, and of course in a large population like our own there are, we may be sure, some of all sorts-men, women, and children-some sick, some sound, some strong, some weak; and we may be also sure that whatever the present strength of any one individual in particular may be, the time must come sooner or later, to each and every one in turn, to hold existence on a precarious tenure, for besides the frailty of infancy and old age, which even under the most favourable circumstances all must face, there are many in the prime of life who have to run the gauntlet of crises, so that there is never lack of scope for the fatal operation of insanitary agents.

If it shall appear that I have given too exclusive prominence to measures relating to the cleansing of the soil and the removal of the effete products of social life, it has not been with a wish to ignore other important considerations-for instance, the maintenance of the purity of food and water, the control of contagion, and the still more hurtful, because more widely prevailing evil, overcrowding. All these and other things have contributed their share in the general result, but on the present occasion we are less concerned in the discussion of the action of sanitation as a whole upon the reduction of the mortalty as we are in the search for the explanation of the special reduction that we have found to occur at certain times of the year under favourable circumstances.

Five-and-twenty years ago no attempt was made to preserve the soil from pollution; privy middens, cesspools, filthy accumulations of house refuse, "sewers of deposit," untended roads and pave. ments, neglected courts and alleys, abounded everywhere. No wonder that disease-producing and death-dealing organisms flourished, and that the death-rate during the summer quarter was nearly 40 per cent. more than it is now. As we well know, a complete change in all these things has taken place; well drained, well scavenged, well looked after in every respect, modern Maidstone has responded bounteously to the efforts that have been put forth for her redemption.

\section{THE STOCKPORT NEW OUTFALL WORKS AND THE GENERAL QUESTION OF TREATMENT OF SEWAGE.}

\section{BY}

\section{Chas. Porter, M.D., M.O.H., Stockport."}

THE sewage and rainfall requiring to be dealt with in the borough are at present discharged direct into the river within the borough from about 30 main-outlet sewers and watercourses. To intercept this sewage and surface-water, very extensive works are being carried out under the supervision of Mr. A. M. Fowler, M.I.C.E., at a cost of over $E_{100,000}$. The principal feature of the engineer's scheme is the provision of five main intercepting sewers.

At the Outfall Works, the sewage will be pumped I 7 feet 6 inches into tanks, there treated ch:mically, and then discharged intermittently upon underdrained and levelled filter beds, through which the effluent thus purified will pass into the river. The Corporation possess 95 acres of land at Heathside Farm, and it is proposed to appropriate by degrees 63 acres for sewage purification. The engineer states that it is well adapted for this purpose, being composed of sharp gravel and sand.

$\mathrm{Mr}$. Fowler has made provision in the outfall sewers for the sewage from upwards of 140,000 peopie, and at the Outfall Works, which can at any time be extended, for dealing with the sewage of 107,400 persons, the figures at which he estimates the population 30 years hence.

These works are now nearly completed, with the exception of the necessary preparation of filter beds and outfall land over which the treated sewage will flow.

Lime will probably be employed as a precipitant, but the exact details of chemical treatment have not yet been finally decided upon. This matter will require most careful consideration if we are to escape the troubles and mistakes in this respect of other large manufacturing towns, especially in regard to money wasted on the use of "patent" precipitants and filtering media, all of which are very costly and more or less inefficient in practice.

With regard to the employment of lime as a precipitant, the tendency undoubtedly is to limit its use to as small a quantity as may be, firstly, because, as has been shown by Mr. Dibdin, the chemist of the London Cuunty Council; an excess of lime dissolves the suspended organic matter of the sewage, greatly adding to the work of filtration; secondly, because the quantity of sludge is proportionately reduced; and thirdly, because an alkaline 
effluent putrefies very offensively with river mud. Mr. Dibdin says that "if the whole of the chemically effective strength of the lime is to be utilised, it must be in solution and not in suspension." In other words, a few grains of lime in solution (i.e, as lime-water) will effect as much work as three or four times the quantity of milk of lime. For London sewage he recommends $3^{*} 7$ grains lime in solution and one grain of protosulphate of iron per gallon of sewage.

With regard to"filtration of sewage, the London County Council has recently published an important record of experiments carried out by Mr. Dibdin, to ascertain the best material for intermittent filtration, burnt ballast, sand, pea-ballast, coke-breeze, and a "proprietary material" being respectively tried, on filter beds ${ }_{200}^{x}$ th of an acre in extent. From a circular letter issued 2 rst Auguit; I 895 , by the owners of this proprietary substance, I learn that the material thus referred to is polarite. Mr. Dibdin's results were as follow :-

r. Purification with coke-breeze exceeded that obtained with any other material, being $6 z^{*} z$ per cent , as compared with $61 \cdot 6$ per cent with polarite, and 43.3 per cent. with burnt ballast.

2. Polarite produces a better-looking effluent than coke-breeze, but the cost of polarite is prohibitrry, and the actual purification it effects is rather less.

3. The conditions of success were found to be porosity, and the consequent power of re-absorbing atmospheric air.

To ascertain the rate at which it was possible to pass tank effluent through a filter, a second series of experiments were carried out-each filter covering one acre-and the following conclusions arrived at, viz. :-

r. That the filter must be gradually brought to its maximum efficiency by cautious increments in the quantity of applied sewage. This condition will be shown by the constantly increasing proportion of nitric acid in the filtrate.

2. That the applied sewage must be left in contact with the micro-organisms by resting in the filter for a sufficient time.

3. That after each effluent has been dealt with, the micro-organisms must be supplied with air, by emptying the filter from below, and thus drawing air through its interstices. The filter must "rest" $f, r$ an hour or more between each filling, and a longer period of aëration, say twenty-four hours, be allowed once a week.

4. The severest frost does not interfere with filtration.

5. That so worked, as much as $1,000,000$ gallons per day may be filtered through one acre of coke-breeze.

6. That the life of such coke-breeze filters is practically without limit.

The coke-breeze filters consisted of powdered. coke-breeze to a depth of four feet, with three inches of super-imposed gravel to keep it from floating.

Similar experiments with cinder and cokebreeze filters were carried out by Sir Henry Roscoe and Mr. de Courcy Meade, in Manchester, from January 22 nd to March 22 nd, 1896 , and in reporting thereupon Sir Henry Roscoe states "that though the true aim of purification, viz., the conversion of the nitrogenous organic matter into inorganic nitrogen, was not attained in the limited time during which the filters were worked, the total purification effected may be on the whole considered satisfactory." He adds that his experience leads him to the opinion that the adoption of artificial filters worked intermittently is a move in the right direction.

It must, moreover, be borne in mind that at the Stockport works the further purifying process of irrigation over suitable land will be superadded to those of precipitation and intermittent filtration.

It may be added that a system of forced aëration of the material used as the filtering medium has recently been tried in this country, air being continuously forced under pressure into the body of the filter, so as to afford the bacteria the necessary means of subsistence. The test of practical working and experience has yet, however, to demonst ate to what extent this method actually possesses the advantages claimed for it.

\section{HOW SMALL-POX CAN BE STAMPED OUT, AN OBJECT LESSON FROM U.S.A.* \\ BY \\ D. S. Davifs, M.D., M.O H. Bristol.}

THE city of Chicago contains somewhat over a million and a ha f (census, $1,567,727$ ) persons, composed of many nationalities, and with a large unsettled or floating population. This city was, in the spring of 1893 , invaded by small-pox-an experience not u.iamiliar in Chicago, and fraught with rec llections of previous disaster. 'Thus, in the $1863^{-6} 5$ epidemic the disease so persisted and continued to spread that the deaths in February and March, 1865 , in the third year of its prevalence, exceed d those in the earlier period of the epidernic; in the $1871-75$ epidemic, extension of the disease continur d over forty-seven months, and in the $1880-83$ epidernic the disease persisted for thirty-nine mont $s$. In con radist inction to these, the epidemic of $1893^{-94}$, although for ten months it progressed and had already assumed formidable proporti $: n s$, leading to 157 deaths in May, 1894 , had its progress checked by very special action during that monih; so that in June there was a reduction of more than one-third of the number

- Tri, a count is taken trom a review s, the An ual Report of the Depaituent ." Healt' of the City of Chicago, for 1895, contributei by Dr. Davies to the Bristol Medicouhirurgical Review. 